UDC 332.1

МРНТИ 06.52.13

DOI: https://doi.org/10.37788/2021-1/ 79-85

\author{
D.S. Bekniyazova ${ }^{1 *}$, Zh.L. Caurkubule ${ }^{2}$ \\ ${ }^{1}$ Innovative University of Eurasia, Kazakhstan \\ ${ }^{2}$ Baltic International Academy, Latvia \\ *(dana.bekniyazova@mail.ru)
}

\title{
Evaluation of regional competitiveness in economic conditions of Kazakhstan
}

\begin{abstract}
Main problem: Issues of evaluating regional competitiveness, search for competitive territories' advantages, especially by improving human resources' quality, remain insufficiently studied. In this regard, in article it is presented existing models for evaluating regional competitiveness in Kazakhstan economy. In addition, in article authors carried out regional classification according to analysis of main socio-economic indicators of Kazakhstan regions, originating in Concept of regional policy. Authors calculated main indicators of Kazakhstan regions' competitiveness with aim of determining level of region's competitiveness in comparative perspective.

Purpose: Purpose of the research is comparative analysis and evaluation of the competitiveness of Kazakhstan's regions in modern conditions.

Methods: The article uses rating model for evaluating competitiveness of Kazakhstan's regions based on indices, developed by Agency for research on investment profitability, operating at National chamber of Entrepreneurs of Kazakhstan (rating of competitiveness of Kazakhstan's regions).

Results and their value: Value of the paper considered in that classification of regions is carried out according to analysis of main socio-economic indicators of Kazakhstan regions, which originates in Concept of regional policy. The authors also calculated main indicators of competitiveness index of Kazakhstan regions according to National chamber of Entrepreneurs of Kazakhstan in order to determine the specifics of regions and identify directions for developing regional strategies. Based on results of the study, analysis was carried out that allowed to reveal strengths and weaknesses of regions of Kazakhstan. It is emphasized that a high level of regional competitiveness cannot be achieved without development of human resources and their rational use. In general, directions of regional policy are determined by chosen development scenario. The approach proposed by authors to methodology for evaluating regional competitiveness has a number of advantages - it reflects the specifics of regions, allows seeing the nearest competitors and determining directions of the region's development strategy.
\end{abstract}

Keywords: regional competitiveness, regional policy, evaluation of human resources, modernization of the economy.

\section{Introduction}

The relevance of the research topic is due to the processes of regionalization in Kazakhstan, accompanied by the redistribution of power competencies, the transfer of functions from the national to the regional level, the emergence and development of institutional forms that correspond to the new role of regions in the implementation of the national development strategy and scenarios for its implementation.

Currently, the existing methods of evaluating the competitiveness of regions, based on the use of separate statistical and mathematical methods, don't allow choosing the optimal trajectory of regional development in the long term. To a greater extent, the research is of a formal nature, since it considers the concept of underdeveloped regions, the factors of socio-economic problems and the classical ways to solve them. This issue is particularly future innovative potential countries.

In this regard, the main idea of the research is to develop a methodology for evaluating the competitiveness of regions, which contributes to the selection of the optimal trajectory of the region's development in the long term..

\section{Materials and methods}

In the most general form, the competitiveness of a region is determined by a combination of different levels of economic, organizational, social and other factors. At the same time, a generalized value of competitiveness that reflects its level and allows determining the current place of regions in competition through the prism of efficiency in solving tactical tasks, which is mainly due to the lack of competitiveness.

Considering competitiveness as an integral category, it is customary to distinguish four groups of indicators that can be used to assess regional competitiveness: indicators);

1. Indicators of the availability and efficiency of the use of resources in the region (economic

2. Indicators of the living standard of application of the proposed system; 
3. Indicators specifics of the regions and activity of the region;

4. Indicators of the regions depend on different factors.

The indicators of the first and second groups most closely reflect the classical approach to evaluating competitiveness proposed by M. Porter, according to which "the competitiveness of a region is the productivity of the use of regional resources, and, first of all, labor and capital, in comparison with other regions, which results in the value of the gross regional product (GRP) per capita, as well as in its dynamics".

Meanwhile, Vasilyeva Z.A. suggests that methodological approaches based on the productivity of regional resources only allow fixing the level of use of regional resources at a given time, which is evidence of their ability to ensure the dynamics of GRP, based more on retrospective data [1].

Consequently, the evaluation of competitiveness through indicators of living standards and economic efficiency of resource use allows determining the current place of regions in competition through the prism of efficiency in solving tactical tasks, but doesn't allow us to judge the competitiveness of any particular region from the point of view of its strategic development.

The authors Samarukha A.V. and Krasnov G.I., in their work note the restrictions on the use of the classical approach offering to focus on investment and future innovative potential, which they are closely associated with the region's ability to generate and reproduce knowledge: "In the creation of competitive advantages of point out that in order to determining the current place of regions in competition through the prism of efficiency in solving tactical tasks, it is necessary to create region" [2]. In continuation of this controversy, other researchers separately identify the category of innovative competitiveness as the most relevant in modern conditions, analyzing the factors that contribute to its increase.

However, the system of factors proposed by the authors is quite difficult to apply. Highlighting the factors that can be quantified, the authors also include the factors for which such assessment may be applied, which complicate the application of the proposed system with a position of strategic regions.

In general, the different level of socio-economic development of regions depends on different factors (geographical, climatic, demographic, etc.).

In economic science, the problem of analyzing the factors that affect the crisis of individual territories and finding tools aimed at increasing their competitiveness in the national and international markets is relevant. In the framework of regional policy, they are divided into 6 groups.

The basis of the grouping that originates from the Concept of regional policy of the Republic of Kazakhstan is the principle of difficulty [3].

Now let us consider the existing assessment models used in practice. In particular, the rating model for point out that in order to increase the competitiveness of a developing country as a whole, it is necessary to create clusters based on the available resources of the regions the Study of Return on Investment operating of the Republic of Kazakhstan [4]. An index approach is rent place of regions in competition through the prism of efficiency in solving tactical tasks, but doesn't allow us to judge the competitiveness of any particular region from the point of view of its strategic development of indicators.

During the determination of the components of the region's competitiveness indices, adequate indicators are chosen that reflect the competitive advantages and innovativeness of the economy.

They must be statistically reliable and objective (the subjective opinion of the researcher in the interpretation should be reduced to zero).

When selecting indicators, the availability of statistics is taken into account.

The competitiveness approach proposed by authors to methodology for evaluating regional competitiveness has a number of advantages - it reflects the specifics of regions, allows seeing the nearest competitors and determining directions of the region's development strategy from 0 to 1 ( 0 indicates the worst result, 1 is the best). Scaling is based on formulas 1 and 2 .

When determining the components of the regional competitiveness indices, the authors selected adequate indicators that reflect the competitive of the economy.

They should be statistically noting the restrictions on the use of the classical approach offering to focus on investment and future innovative potential should be reduced to zero). When selecting indicators, the availability of statistical information is taken into account.

$$
\begin{aligned}
& K_{n}^{i}=Y_{n}^{i}-Y_{n i n i} / Y_{m a x i}-Y_{m i n t} \\
& K_{n}^{i}=1-Y_{n}^{i}-Y_{m i n t} / Y_{m a x t}-Y_{m i n t}
\end{aligned}
$$

where,

$Y_{n}^{2}-\mathrm{n}$ is the index of the $\mathrm{i}$-th region;

$Y_{m i n t}$ - the minimum value of the indicator for all regions of the sample;

$Y_{\text {maxt }}$ - the maximum value of the indicator for all regions. 
Formula 1 is used if the maximum value corresponds to the best result. Otherwise, apply the formula 2. Let us determine the arithmetic average of indices necessary for the calculation of the integrated coefficient using formula 3 .

$$
\mathrm{K}_{\text {arith. mean }}=\sum_{n-1}^{m} K_{n}^{l}
$$

The resulting result is transformed by the formula 4 :

$$
K_{\text {arith. mean }}=K_{\text {enthemean } n}^{t}-K_{\text {anthhmean mint }}^{t} / K_{\text {anth mean maxt }}^{t} K_{\text {anthemean mint }}^{t}
$$

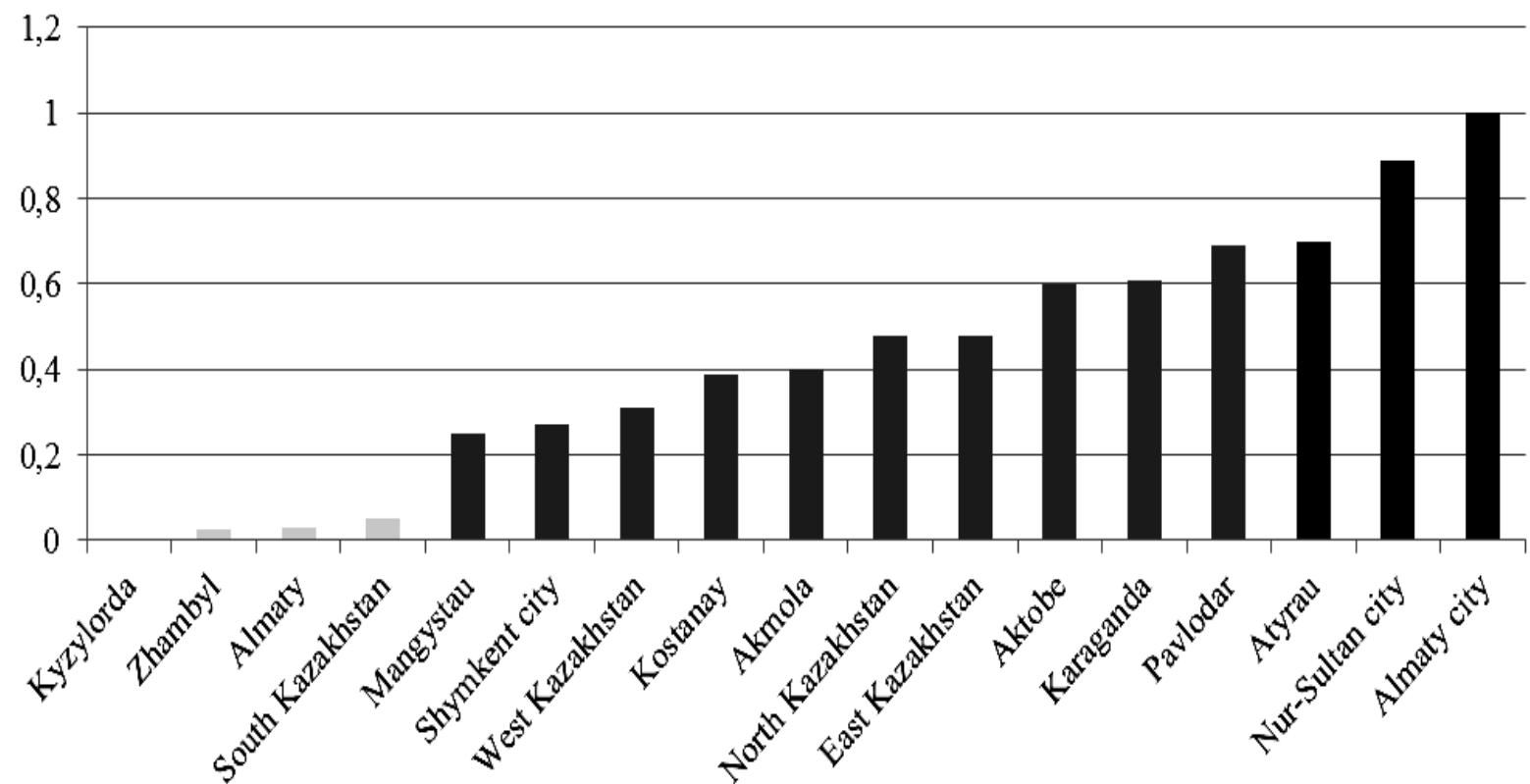

Note - Compiled by the author according to the National Chamber of Entrepreneurs of the Republic of Kazakhstan [4]

Figure 1 - Regional Competitiveness Index in 2018

\section{Results}

Transformations made it possible to rank the regions of the Republic of Kazakhstan by a general indicator of competitiveness and by private indices, which evaluate a particular sphere.

According to these indicators, the most competitive regions are Nur-Sultan city (Astana), Almaty city and Atyrau region. They are distinguished by high rates of GRP per capita, investments in fixed assets, the number of small businesses, and a high level of human resources development.

Regions with stable rent place of regions in competition through the prism of efficiency in solving tactical tasks, but don't allow us to judge the competitiveness of any particular region from the point of view of its strategic development infrastructure.

The regions located in the south of Kazakhstan are less competitive.

They are South Kazakhstan, Zhambyl, Kyzylorda, Shymkent ciy, Mangystau regions, West Kazakhstan and Almaty regions. But at the same time, the latter region shows an above average human development index in comparison with other regions of this list.

Economists often point out that in order to increase the competitiveness of a developing country as a whole, it is necessary to create clusters based on the available resources of the regions.

However, there are serious disparities between the socio-economic development of individual territorial units. $37,5 \%$ of the regions have low competitiveness.

None of them was able to show a high level of productivity, including regions with a high level of human resource development.

Another significant study on the assessment of the competitiveness of the regions of Kazakhstan was conducted by the "SANDZH" Research and Development Center for the Regional Development Department of the Ministry of national economy of Kazakhstan [5].

According to the data of the research center "SANDZH", the authors conducted a ranking of the regions, which was carried out according to key statistical indicators for 2013-2018 (table 1). 
Table 1 - Ranking of regions of the Republic of Kazakhstan for 2013-2018

\begin{tabular}{|l|c|c|c|c|}
\hline \multicolumn{1}{|c|}{ Region } & $\begin{array}{c}\text { The final place } \\
\text { in the rating }\end{array}$ & $\begin{array}{c}\text { Place in the ranking } \\
\text { of economic } \\
\text { development }\end{array}$ & $\begin{array}{c}\text { Place in social } \\
\text { development } \\
\text { rating }\end{array}$ & $\begin{array}{c}\text { Place in the ranking } \\
\text { of investments in } \\
\text { education and } \\
\text { health }\end{array}$ \\
\hline Nur-Sultan city (Astana) & 1 & 5 & 1 & 1 \\
\hline Atyrau & 2 & 1 & 4 & 4 \\
\hline Almaty city & 3 & 3 & 7 & 2 \\
\hline Aktobe & 4 & 2 & 9 & 5 \\
\hline Mangystau & 5 & 4 & 11 & 7 \\
\hline Pavlodar & 6 & 6 & 10 & 7 \\
\hline West Kazakhstan & 7 & 8 & 12 & 14 \\
\hline Karaganda & 8 & 10 & 6 & 12 \\
\hline Almaty & 9 & 11 & 16 & 10 \\
\hline Kyzylorda & 10 & 14 & 15 & 9 \\
\hline East Kazakhstan & 11 & 7 & 13 & 11 \\
\hline Kostanay & 12 & 9 & 14 & 13 \\
\hline North Kazakhstan & 13 & 13 & 4 & \\
\hline Akmola & 14 & 12 & 5 & 15 \\
\hline Shymkent & 15 & 15 & 7 & 16 \\
\hline South Kazakhstan & 16 & 16 & & \\
\hline Zhambyl & 17 & 17 & & \\
\hline Note - compiled by the authors based on the source $[6]$ & & & \\
\hline
\end{tabular}

This made possible to determine the competitive advantages of each territorial unit and zone of possible growth and development. The analysis is based on indicators that are available on the Committee on Statistics of the Ministry of national economy of Kazakhstan [6].

The methodological framework includes 19 indicators grouped into three categories: economic, social, and investment in education and health. The latter, in turn, are the basis for the development of human resources. To bring the results to the same units of measurement, they are considered as a percentage. Building regions in accordance with the obtained values allows to determine their problematic status in comparison with other territories. The results of the study are interpreted as follows: required.

$1^{\text {st }}-6^{\text {th }}$ place - regions with good competitiveness. The intervention of the executive authorities is not

$7^{\text {th }}-10^{\text {th }}$ place - regions with stable competitiveness. The executive branch controls their socioeconomic development and conducts targeted measures to improve efficiency in certain areas of the economy.

$11^{\text {th }}-16^{\text {th }}$ place - regions with low competitiveness. Regular government intervention is required to improve the effectiveness of regional policy.

In the course of the study, the regions rent place of regions in competition through the prism of efficiency in solving tactical tasks, but doesn't allow us to judge the competitiveness of any particular region from the point of view of its strategic development.

They are ranked from place of regions in competition through the prism of efficiency in solving tactical tasks, but doesn't allow us to judge the competitiveness of any particular region from the point of view of its strategic development South Kazakhstan and Zhambyl regions (from $11^{\text {th }}$ to $16^{\text {th }}$ place).

As a result, this ranking showed that a high level of investment in education and healthcare, as the main areas of human resource development, is characteristic of the regions that occupy the first places in the final competitiveness rating.

\section{Discussion}

The analysis allows to identify the strengths and weaknesses. For example, the city of Nur-Sultan (Astana), not being a region of the extractive industry, took the fifth place in the rating for economic development, thanks to the indicator of innovative development and efficient non-productive sector of the economy.

The city of Almaty is characterized by social problems: a high level of crime and inflated prices for a grocery basket. The first problem is associated with a large number of migrants (a large city in the border area), the second-with the excess of demand for goods and services over supply (caused by the incomes of residents above the average). Nevertheless, growing investments in education, a high level of literacy and life expectancy above average, allowed the city of republican significance to come out on top in the final ranking. problems.

Atyrau and Mangystau regions, which are in the TOP 5 of the compiled rating, also have a number of

They are mainly related to the raw materials orientation of the regional economy. They are indicated by low indicators of the volume of industry per person and high prices. 
South Kazakhstan, Shymkent city and Zhambyl regions have the lowest level of investment in education and healthcare. These same regions also took the last places in the final competitiveness rating. South Kazakhstan region takes the 16 th place in the final rating.

However, according to the integrated social indicator, it is among the top 5, which is due to the low level of mortality from cancer and positive population growth. In the last place is the Zhambyl region, which is caused, in addition to the problems of education and health, also by the valuable for the analysis of human resources. According to the crime rate, it ranks 7th.

Irregular development of the regions is also observed in terms of industrial production per person, agricultural output, provision of services, etc. There is a significant gap in the social indicators for assessing the regions of Kazakhstan.

One of the indicators of the social and economic well-being of the nominal wage in the region (надо пересмотреть предложение, так ак нет оригинала я не могу исправить, предложение не полное). The average monthly salary in the WKR is among the top 5 in Kazakhstan. The size of the nominal wages in WKR is higher than in most other regions, the exception is Atyrau and Mangystau regions, and Nur-Sultan (Astana) and Almaty cities.

That kind of highest wage rate trend is typical for oil and gas production enterprises, oil refining and engineering industries. Indicator of nominal wages is valuable for the analysis of human resources. Wages are the largest share in valuable for the analysis of human resources.

The scope of entrepreneurship is underdeveloped. The slowdown in the development of micro and small businesses is a negative trend characterizing a decrease in the competitiveness of a territory.

\section{Conclusion}

Thus, a high level of competitiveness of a region cannot be achieved without the development of human resources and their optimal use. This is necessary for lagging regions since they have a number of serious problems:

- Imbalance between specifics of the regions for human resources;

- lack of material financial resources to realize human resource development strategies;

- the lag of human resources development from the requirements of an innovative economy;

- the discrepancy between territory for the so-called creative class competitiveness has a number specifics of the regions development.

The conclusions of the study are confirmed by the fact that in modern socio-economic conditions, regional competition is acquiring new features: in addition to traditional sources of advantages, more and more importance is attached to the sources of economic growth, the nature of which is immaterial.

These sources are based on talent, tolerance, and technologies that are "rooted" in the region and characterize its creativity as a measure of assessing the attractiveness of the territory for the so-called creative class, whose contribution to the economy is significant.

The assessment of competitiveness is thus conducted through the prism of creativity, which combines three equivalent factors: the factors of technology, talent and tolerance.

In this case, our proposed approach to the methodology for assessing regional competitiveness has a number of advantages - it reflects the specifics of the regions, allows seeing the nearest competitors and determining the directions of the region's development strategy.

\section{THE LIST OF SOURCES}

1 Васильева 3.А. Иерархия понятий конкурентоспособности субъектов рынка / 3.А. Васильева // Маркетинг в России и за рубежом. - 2016. - № 2. - С. 35-37.

2 Самаруха А.В., Краснов Г.И. Факторы обеспечения конкурентоспособности региона / А.В. Самаруха, Г.И. Краснов // Известия Иркутской Государственной Экономической Академии. - 2015. - № 6. - С. 20 27.

3 Постановление Правительства Республики Казахстан от 9 сентября 1996 г. № 1097 (утратил силу) «Концепция региональной политики Республики Казахстан». [Электронный ресурс]. - Режим доступа: http://adilet.zan.kz/rus/docs/P960001097

4 Рейтинг конкурентоспособности регионов Казахстана. - Астана: Национальная палата Предпринимателей Республики Казахстан. - 2018. - 159 с.

5 Конкурентоспособность регионов Казахстана. - Астана: НИЦ «САНДЖ», 2018. - 98 с.

6 Регионы Казахстана: статистический ежегодник. - Астана: Комитет по статистике Министерства национальной экономики РК. - 2018. - 134 с.

\section{REFERENCES}

1 Vasileva, Z.A. (2016). Ierarhija ponjatij konkurentosposobnosti sub'ektov rynka [Hierarchy of concepts of competitiveness of market subjects]. Marketing v Rossii i za rubezhom - Marketing in Russia and abroad, 2, 3537 [In Russian]. 
2 Samarukha, A.V., Krasnov, G. I. (2015). Faktory obespechenija konkurentosposobnosti regiona [Factors of ensuring the competitiveness of the region]. Izvestija Irkutskoj Gosudarstvennoj Jekonomicheskoj Akademii Proceedings of the Irkutsk State Economic Academy, 6, 20-27 [In Russian].

3 Postanovlenie Pravitelstva Respubliki Kazaxstan ot 9 sentyabrya 1996 g. № 1097 (utratil silu) "Koncepciya regionalnoj politiki Respubliki Kazaxstan" [Resolution of the Government of the Republic of Kazakhstan No. 1097 of September 9, 1996 (expired) "The concept of regional policy of the Republic of Kazakhstan"]. (n.d.). adilet.zan.kz. Retrieved from http://adilet.zan.kz/rus/docs/P960001097 [In Russian].

4 Rejting konkurentosposobnosti regionov Kazaxstana [Rating of competitiveness of the regions of Kazakhstan] (2018). - Astana: Nacionalnaya Palata Predprinimatelej Respubliki Kazaxstan - National chamber of entrepreneurs of the Republic of Kazakhstan [In Russian].

5 Konkurentosposobnosti regionov Kazaxstana [Competitiveness of the regions of Kazakhstan] (2018). Astana: NIC "SANDZH" [In Russian].

6 Regiony Kazaxstana: statisticheskij ezhegodnik (2018) [Regions of Kazakhstan: statistical yearbook]. Astana: Komitet po statistike Ministerstva nacionalnoj ekonomiki RK - Committee on Statistics of the Ministry of National Economy of the Republic of Kazakhstan [In Russian].

\author{
Д.С. Бекниязова ${ }^{1}$, Ж.Л. Цауркубуле ${ }^{2}$ \\ ${ }^{1}$ Инновациялық Еуразия университеті, Қазақстан \\ ${ }^{2}$ Балтық Халықаралық академиясы, Латвия
}

\title{
Қазақстанның экономикалық жағдайларында өңірлердің бәсекеге қабілеттілігін бағалау
}

Аймақтардың бәсекеге қабілеттілігін бағалау, аймақтардың бәсекелестік артықшылықтарын іздеу мәселелері, әсіресе адам ресурстарының сапасын арттыру есебінен жеткілікті зерттелмеген күйінде қалып отыр. Осыған байланысты мақалада Қазақстан Республикасының экономикасы жағдайында аймақтық бәсекеге қабілеттілікті бағалаудың қолда бар үлгілері берілген. Бұдан басқа, мақала авторлары аймақтық саясат тұжырымдамасында бастау алатын Қазақстан Республикасы аймақтарының негізгі әлеуметтік-экономикалық көрсеткіштерін талдауға сәйкес аймақтардың топтастырылуын жүзеге асырған. Авторлар Қазақстан Республикасының салыстырмалы аспектіде аймақтың бәсекеге қабілеттілік деңгейін анықтау мақсатында Қазақстан аймақтарының бәсекеге қабілеттілік индексінің негізгі көрсеткіштерін есептеп берген.

Зерттеу мақсаты - қазіргі жағдайдағы Қазақстан аймақтарының бәсекеге қабілеттілігін салыстырмалы талдау және бағалау.

Мақалада Қазақстан Республикасының Ұлттық Кәсіпкерлер палатасы жанынан әрекет ететін инвестициялардың өтімділігін зерттеу жөніндегі Агенттік (Қазақстан өңірлерінің бәсекеге қабілеттілік рейтингі) әзірлеген индекстердің негізінде Қазақстан өңірлерінің бәсекеге қабілеттілігін бағалаудың рейтингтік үлгісі қолданылды.

Зерттеудің құндылығы - өңірлік саясат тұжырымдамасынан бастау алатын Қазақстан Республикасы өңірлерінің негізгі әлеуметтік-экономикалық көрсеткіштерін талдауға сәйкес өңірлерді жіктеу жүзеге асырылды. Авторлар өңірлердің ерекшелігін айқындау және өңірлердің стратегиясын әзірлеу бағыттарын анықтау мақсатында Қазақстан Республикасының Ұлттық Кәсіпкерлер палатасының мәліметтері бойынша Қазақстан өңірлерінің бәсекеге қабілеттілік индексінің негізгі көрсеткіштері есептелген. Зерттеу нәтижелері бойынша Қазақстан өңірлерінің күшті және әлсіз жақтарын анықтауға мүмкіндік берген талдау жүргізілді. Аймақтың бәсекеге қабілеттілігінің жоғары деңгейіне адам ресурстарын дамытпай және оларды ұтымды пайдаланбай қол жеткізу мүмкін емес екендігі атап өтілді. Тұтастай алғанда, өңірлік саясаттың бағыттары дамудың таңдалған сценарийімен айқындалады. Авторлар ұсынатын өңірлік бәсекеге қабілеттілікті бағалау әдіснамасына көзқарас бірқатар артықшылықтарға ие-өңірлердің ерекшелігін көрсетеді, жақын арадағы бәсекелестерді көруге және өңірдің даму стратегиясының бағыттарын анықтауға мүмкіндік береді.

Түйін сөздер: аймақтардың бәсекеге қабілеттілігі, аймақтық саясат, адам ресурстарын бағалау, экономиканы жаңғырту.

\author{
Д.С. Бекниязова ${ }^{1}$, Ж.Л. Цауркубуле \\ ${ }^{1}$ Инновационный Евразийский университет, Казахстан \\ ${ }^{2}$ Балтийская Международная Академия, Латвия
}

\section{Оценка конкурентоспособности регионов в экономических условиях Казахстана}

Вопросы оценки конкурентоспособности регионов, поиск конкурентных преимуществ территорий, особенно за счет повышения качества человеческих ресурсов, остаются недостаточно изученными. В связи с этим в статье представлены имеющиеся модели оценки региональной конкурентоспособности в условиях экономики Республики Казахстан. Кроме того, в статье авторами осуществлена классификация регионов согласно анализу основных социально-экономических 
показателей регионов Республики Казахстан, берущей начало в Концепции региональной политики. Авторами рассчитаны основные показатели индекса конкурентоспособности регионов Казахстана с целью определения уровня конкурентоспособности регионов в сравнительном аспекте.

Целью исследования является сравнительный анализ и оценка конкурентоспособности регионов Казахстана в современных условиях. В статье использована рейтинговая модель оценки конкурентоспособности регионов Казахстана на основе индексов, разработанная Агентством по исследованию рентабельности инвестиций, действующим при Национальной палате Предпринимателей Республики Казахстан (рейтинг конкурентоспособности регионов Казахстана).

Значимость исследования заключается в том, что осуществлена классификация регионов согласно анализу основных социально-экономических показателей регионов Республики Казахстан, берущей начало в Концепции региональной политики. Авторами рассчитаны основные показатели индекса конкурентоспособности регионов Казахстана по данным Национальной палаты Предпринимателей Республики Казахстан с целью определения специфики регионов и выявления направлений разработки стратегии регионов. По результатам исследования проведен анализ, который позволил выявить сильные и слабые стороны регионов Казахстана. Подчеркнуто, что региону невозможно достигнуть высокого уровня конкурентоспособности без развития человеческих ресурсов и рационального их использования. В целом, направления региональной политики определяются выбранным сценарием развития. Предлагаемый авторами подход к методологии оценки региональной конкурентоспособности, имеет ряд преимуществ - отражает специфику регионов, позволяет увидеть ближайших конкурентов и определить направления стратегии развития региона.

Ключевые слова: конкурентоспособность регионов, региональная политика, оценка человеческих ресурсов, модернизация экономики.

Date of receipt of the manuscript to the editor: $2021 / 02 / 25$ 